Jan Koleśnik

Szkoła Glówna Handlowa w Warszawie

\title{
Uwarunkowania funkcjonowania systemów gwarantowania depozytów i ich wpływ na zachowania deponentów
}

\section{DETERMINANTS OF THE FUNCTIONING OF DEPOSIT GUARANTEE SCHEMES AND THEIR IMPACT ON DEPOSITORS' BEHAVIOR}

\begin{abstract}
Celem artykulu jest przedstawienie społecznych przesłanek tworzenia $i$ konsekwencji istnienia systemów gwarantowania depozytów. Zdaniem autora istnienie systemów gwarantowania depozytów sprawia, iż staja się one istotnym elementem, wzmacniajacym więzi pomiędzy deponentami $i$ bankami, natomiast ich ksztalt jest pochodnq zaburzeń $i$ zdarzeń kryzysowych $w$ sektorze bankowym. Zestawiajac społeczne koszty utworzenia i funkcjonowania systemu gwarantowania depozytów z kosztami skutków paniki na rynku bankowym wskazuje zaś, iż kosztami bezpośrednimi sq przede wszystkim sktadki płacone przez banki, które zmniejszaja oprocentowanie depozytów i zwiększaja koszt kredytu bankowego dla społeczeństwa. Kosztem pośrednim jest zaś wzrost ryzyka powstania pokusy nadużycia oraz osłabienie bodźców do zwiększania wiedzy deponentów w zakresie ekonomii i finansów.
\end{abstract}

Slowa kluczowe: system bankowy, system gwarantowania depozytów, moral hazard

\section{Wprowadzenie}

Budową i sprawnym działaniem systemu ochrony nieprofesjonalnych uczestników rynku jest zainteresowane nie tylko państwo (aspekt społeczno-ekonomiczny), ale również sami uczestnicy rynku (aspekt ekonomiczny). Banki są bowiem świadome, iż koszty uczestnictwa $\mathrm{w}$ tego typu systemach są niewspółmiernie niskie do strat, które mogą powstać na skutek masowego wycofywania środków w następstwie utraty zaufania klientów do solidności systemu finansowego. Dla państwa zaś ochrona nieprofesjonalnych deponentów stanowi niezbędne uzupełnienie systemu nadzoru nad instytucjami finansowymi ${ }^{1}$.

Powstaje jednak pytanie czy obecne zasady gwarantowania depozytów, jakie obowiązują w krajach Unii Europejskiej oraz zmiany, jakie miały w nich miejsce podczas ostatniego kryzysu nie spowodują negatywnych długoterminowych skutków społecznych w postaci całkowitego braku zainteresowania sytuacją ekonomiczną banków, którym deponenci powierzają swoje oszczędności oraz wzrostu ryzyka pokusy

\footnotetext{
${ }^{1}$ P. Bagus, D. Howden: The economic and legal significance of "full" deposit availability, European Journal of Law and Economics 2016, Volume 41, Issue 1, s. 244 - 247.
} 
nadużycia polegającego na świadomym deponowaniu środków w bankach o złej kondycji jedynie na podstawie wysokości oferowanego przez nie oprocentowania ${ }^{2}$.

Celem niniejszego artykułu jest przedstawienie społecznych przesłanek tworzenia i konsekwencji istnienia systemów gwarantowania depozytów. Regulacje prawne (zarówno unijne jak i polskie) w zakresie ochrony deponentów oraz reakcja deponentów na upadłość Spółdzielczego Banku Rzemiosła i Rolnictwa w Wołominie będą zaś punktem wyjścia do odpowiedzi na pytanie o ewentualne, negatywne skutki, istnienia gwarantowania depozytów nie tylko dla bezpieczeństwa sektora bankowego, ale także postaw deponentów oraz wpływu na ich motywację do pogłębiania swojej wiedzy w zakresie ekonomii i finansów.

\section{Społeczne przesłanki tworzenia systemów gwarantowania depozytów}

Wyjaśniając celowość istnienia systemów gwarantowania depozytów trzeba po pierwsze wskazywać na ich rolę w ograniczaniu spadku zaufania deponentów do sektora bankowego w czasie zaburzeń i kryzysu. Po drugie jednak biorąc pod uwagę, iż celem funkcjonowania podmiotów gospodarczych jest zapewnienie trwałości stosunków gospodarczych w zmiennym otoczeniu rynkowym trzeba wskazać, iż zasady systemów gwarantowania depozytów stają się istotnym elementem, wzmacniającym więzi pomiędzy deponentami i bankami ${ }^{3}$.

Przyczyny powstawania systemów gwarantowania depozytów mogą być jednak jedynie pośrednio związane $\mathrm{z}$ funkcjonowaniem systemu bankowego $\mathrm{w}$ danym kraju i mieć charakter przede wszystkim polityczny. Powołanie do życia systemu gwarantowania depozytów zawsze będzie bowiem eksponowane jako sukces polityków, którzy się do tego przyczynili. W krótkim okresie można szczególnie eksponować potencjalne korzyści takiego systemu, jak chociażby ochrona najmniej zamożnych deponentów. Stopień rozwoju systemu bankowego oraz otoczenia prawno-regulacyjnego w danym kraju także ma istotny wpływ na powstawanie systemów gwarantowania depozytów. W krajach wysokorozwiniętych podstawowymi przesłankami tworzenia tego typu systemów jest wskazana wcześniej potrzeba zapewnienia bezpieczeństwa systemu bankowego oraz ochrony nieprofesjonalnych uczestników rynku, natomiast w krajach rozwijających się przesłanki te mają często charakter zewnętrzny i wynikają $z$ programów pomocowych realizowanych pod patronatem instytucji międzynarodowych ${ }^{4}$.

Istnienie skutecznego systemu gwarantowania depozytów może być traktowane jako dodatkowy atut danego systemu bankowego i powodować powstanie swoistej przewagi konkurencyjnej nad systemami bankowymi z krajów, w których takie systemy nie występują. Utworzenie systemu gwarantowania depozytów w danym kraju powoduje wzrost zainteresowania bankami z tego kraju nie tylko przez deponentów, których depozyty podlegają ochronie, ale także przez pozostałych klientów, w tym inne banki. Kluczowy jest jednak sposób postrzegania całego systemu bankowego w danym kraju,

\footnotetext{
${ }^{2}$ M. C. Bergbrant, K. C. Campbell, D. M Hunter, J. E. Owers: Does deposit insurance retard the development of non-bank financial markets? Journal of Banking and Finance 2016, Volume 66, s. 105.

${ }^{3}$ R. Cooper, H. Kempf: Deposit insurance and bank liquidation without commitment: Can we sleep well? Economic Theory 2016, Volume 61, Issue 2, s. 366-368.

${ }^{4}$ A. Demirgüç-Kunt, E. J Kane, L. Laeven: Determinants of deposit-insurance adoption and design, Journal of Financial Intermediation 2008, Volume 17, Issue 3, s. 407-438.
} 
który sprawia, iż systemy gwarantowania depozytów w krajach wysokorozwiniętych są co do zasady lepiej oceniane i darzone większym zaufaniem przez deponentów i podmioty zagraniczne niż systemy krajów rozwijających się $e^{5}$. Tym samym można stwierdzić, iż próby zachęcania deponentów i podmiotów z innych krajów do lokowania środków w lokalnym systemie bankowym tylko poprzez zmiany zasad działania i zakresu ochrony systemów gwarantowania depozytów są niecelowe. Co więcej konkurencja pomiędzy systemami gwarantowania depozytów z różnych krajów może okazać się szkodliwa ${ }^{6}$.

\section{Wpływ istnienia systemów gwarantowania depozytów na zachowania deponentów}

W literaturze przedmiotu system gwarantowania depozytów jest wskazywany, jako element sieci bezpieczeństwa, osłabiający oddziaływanie rynkowe. Deponenci, których depozyty objęte są całkowitą ochroną tracą motywację do monitorowania sytuacji banku, czy też analizowania informacji na jego temat. Prowadzi to do stopniowego zaniku zainteresowania sytuacją zarówno pojedynczych banków jak i systemu bankowego jako całości. Jedynie istnienie ograniczonego systemu ochrony części deponentów może prowadzić do wzrostu sytuacją banku. Co do zasady istnienie systemów gwarantowania depozytów obniża jednak poziom dyscypliny rynkowej przy czym jej poziom jest negatywnie skorelowany z wysokością środków gwarantowanych, jak też udziałem instytucji państwowych w systemie gwarantowania depozytów. Istnienie sformalizowanego systemu gwarantowania depozytów nie tylko wpływa na wysokość oprocentowania oferowanego przez banki i jego wrażliwość na ponoszone ryzyko, ale także na wysokość premii za ryzyko, jakiej oczekują deponenci. Premia za ryzyko zależy od istnienia i zasad funkcjonowania systemu gwarantowania depozytów na danym rynku, jednak jej wysokość determinują m. in. takie czynniki jak: wiarygodność systemu gwarantowania oraz wpływ jego funkcjonowania na ryzyko pokusy nadużycia ${ }^{7}$. Szczególnie istotne może to być dla deponentów, których depozyty z uwagi na ich wysokość nie są w pełni objęte ochroną systemu gwarantowania.

Cechami systemów gwarantowania, które wzmacniają reakcję deponentów, prowadząc do wzmożonych wypłat depozytów są:

- niski limit środków gwarantowanych,

- udział własny deponenta,

- system zarządzania oparty o podmioty prywatne,

- dobrowolne uczestnictwo banków w systemie,

- imitowany zakres ochrony.

Natomiast do cech osłabiających reakcje deponentów można zaliczyć:

- wysoki limit środków gwarantowanych,

- szeroki zakres ochrony, obejmujący depozyty walutowe,

\footnotetext{
${ }^{5}$ H. Huizinga, G. Nicodème: Deposit insurance and international bank liabilities, Journal of Banking and Finance 2006, Volume 30, Issue 3, s. 965-987.

${ }^{6}$ J. Koleśnik: Bezpieczeństwo systemu bankowego. Teoria i praktyka, Difin, Warszawa 2011, s. 265.

7 J. Bartholdy, G. W. Boyle, R. D. Stover: Deposit insurance and the risk premium in bank deposit rates, Journal of Banking and Finance 2003, Volume 27, Issue 4, s. 699-717.
} 
- system finansowania ex ante (istnienie skumulowanych zasobów w samym systemie),

- udział rządu w zarządzaniu systemem.

Wpływ wskazanych powyżej czynników na reakcje deponentów można zaobserwować także na podstawie zdarzeń, jakie miały miejsce w polskim sektorze bankowym w związku z upadłością Spółdzielczego Banku Rzemiosła i Rolnictwa w Wołominie (SBRiR), do której doszło w 2015 roku. Wypłata środków gwarantowanych deponentom banku w związku ze spełnieniem warunku gwarancji wobec SBRiR - objęła 33,1 tys. deponentów, a łączna wartość środków gwarantowanych wyniosła 2.036,9 mln $\mathrm{zl}^{8}$. Dniem spełnienia warunku gwarancji, czyli dniem, w którym deponenci SBRiR utracili dostęp do swoich depozytów był 23 listopada 2015 r. Osoby te przez 5 kolejnych dni roboczych, tj. do momentu rozpoczęcia wypłat przez BFG środków gwarantowanych były pozbawione możliwości korzystania ze swoich oszczędności. Z uwagi na fakt, iż sytuacja ta dotknęła ponad 33 tys. obywateli a łączna kwota „zablokowanych” środków przekroczyła 2 mld zł można było oczekiwać reakcji deponentów innych banków, którzy mogli podjęć decyzję o wycofaniu swoich oszczędności z banków. Dane opublikowane przez Urząd Komisji Nadzoru Bankowego wskazuja jednak, iż taka sytuacja nie miała miejsca a poziom depozytów gospodarstw domowych w polskich bankach systematycznie rósł zarówno w ostatnim kwartale 2015 r., jak i w pierwszym kwartale roku następnego. Widoczne zmniejszenie się stanu depozytów gospodarstw domowych w bankach spółdzielczych na koniec listopada 2015 r. było spowodowane faktem, iż BFG rozpoczął wypłatę środków gwarantowanych 30 listopada a zatem środki te nie były już ujmowane jako depozyty gospodarstw domowych w bankach. Jednak już po miesiącu stan depozytów gospodarstw domowych w bankach spółdzielczych powrócił do stanu na koniec października co oznacza, iż deponenci którzy otrzymali wypłatę z BFG ponownie ulokowali swoje środki w bankach spółdzielczych (tabela 1). Tym samym można stwierdzić, iż deponenci polskich banków, pomimo upadłości SBRiR, nie mieli wątpliwości co do skuteczności ochrony zapewnianej przez funkcjonujący systemem gwarantowania depozytów biorąc pod uwagę wysoki limit środków gwarantowanych, szeroki zakres ochrony oraz reputację BFG.

Tabela 1. Depozyty gospodarstw domowych w polskim sektorze bankowym w okresie od IX 2015 do III 2016 (w mld zt)

\begin{tabular}{|c|c|c|c|c|c|c|c|}
\hline \multirow{5}{*}{$\begin{array}{r}\text { w polskim sektorze } \\
\text { bankowym, w tym: } \\
\text { bankach } \\
\text { komercyjnych } \\
\text { bankach } \\
\text { spółdzielczych }\end{array}$} & \multicolumn{6}{|c|}{ Stan depozytów gospodarstw domowych (w mld zl) na koniec } & \\
\hline & IX 2015 & X 2015 & XI 2015 & XII 2015 & I 2016 & II 2016 & III 2016 \\
\hline & 638,7 & 645,1 & 650,2 & 665,7 & 673,3 & 679,1 & 683,0 \\
\hline & 563,0 & 568,3 & 574,5 & 589,0 & 595,7 & 601,2 & 604,3 \\
\hline & 75,6 & 76,7 & 75,8 & 76,7 & 77,6 & 77,9 & 78,7 \\
\hline
\end{tabular}

Źródło: Sektor bankowy dane 2016, Urząd Komisji Nadzoru Bankowego, Warszawa 2017, s. 4.

\footnotetext{
${ }^{8}$ Raport Roczny BFG za 2015 rok, Bankowy Fundusz Gwarancyjny, Warszawa 2016, s. 30.
} 


\section{Ewolucja zasad gwarantowania depozytów w Unii Europejskiej i w Polsce}

Obecny kształt ochrony depozytów w bankach w krajach UE jest wynikiem ewolucji, jak miała miejsce $\mathrm{w}$ regulacjach unijnych $\mathrm{w}$ wyniku ostatniego kryzysu. Budując wspólny rynek usług finansowych od samego początku dużą wagę przywiązywano do zapewnienia mu jak największej stabilności i bezpieczeństwa. Dlatego też w pierwszej kolejności podjęto prace nad ujednoliceniem istniejących w państwach UE systemów gwarantowania depozytów bankowych różniących się zarówno co do formy prawnej (instytucje prawa publicznego jak i prywatnego), zasad uczestnictwa banków (obligatoryjność lub fakultatywność) czy też przyjętego zakresu gwarancji depozytów. Prace te zaowocowały uchwaleniem Dyrektywy Parlamentu Europejskiego i Rady 94/19/WE z dnia 30 maja 1994 r. w sprawie systemu gwarantowania depozytów ${ }^{9}$, która ustaliła ujednolicone minimalne wymagania dotyczące systemów ochrony depozytów. Do najważniejszych postanowień tej dyrektywy należało, m.in. określenie minimum kwoty gwarantowanej dla jednego deponenta na 20000 euro oraz dopuszczenie możliwości ustalenia udziału własnego deponentów (do 10\% wartości depozytu) jednak bez naruszania limitu 20.000 euro. Kluczowe postanowienia tej dyrektywy obowiązywały w niezmienionym kształcie prawie 15 lat. Dopiero w IV kw. 2008 r. na skutek zawirowań na światowych rynkach finansowych podjęto prace zmierzające do nowelizacji Dyrektywy w kierunku zwiększenia poziomu harmonizacji systemów gwarantowania depozytów utworzonych w państwach UE. W dniu 18 grudnia 2008 r. Parlament Europejski przyjął nowelizację dyrektywy, mocą której dokonano zmian w dwóch kluczowych obszarach tj. w zakresie wysokości limitu gwarancyjnego oraz do terminu wypłaty depozytów objętych gwarancjami ${ }^{10}$. Uznano, iż dotychczasowy trzymiesięczny termin wypłaty świadczeń gwarancyjnych jest sprzeczny z potrzebą utrzymania zaufania deponentów i nie odpowiada ich potrzebom. W związku z tym, został on skrócony do dwudziestu dni roboczych. Drugą ważną zmianą zawartą w nowelizacji, wymagającą wdrożenia do końca 2010 r. było podniesienie wysokości gwarancji. Do dnia 31 grudnia 2010 r. wysokość gwarancji depozytów dla jednego deponenta miała zostać ustalona na poziomie 100000 euro. Zmiana gwarancji do poziomu 100000 euro miała przy tym wymiar harmonizacji wysokości gwarancji we wszystkich krajach członkowskich na jednorodnym poziomie.

Jednym z głównych filarów europejskiej unii bankowej, obok jednolitego europejskiego systemu nadzoru bankowego, jest koncepcja wspólnych ram w zakresie gwarancji depozytów oraz restrukturyzacji i uporządkowanej likwidacji banków. Przy czym wspólny system gwarantowania depozytów miałby powstać pod nadzorem wspólnego organu restrukturyzacyjnego. Projekt stosownego rozporządzenia Parlamentu Europejskiego i Rady w sprawie utworzenia Europejskiego Systemu Gwarantowania Depozytów został zaprezentowany w dniu 24 listopada 2015 roku. Pomimo, iż prace nad nim wciąż trwają trzeba odnotować, iż wprowadzenie proponowanych w nim rozwiązań będzie istotnym przełomem $\mathrm{w}$ zakresie podejścia do unijnych zasad gwarantowania

\footnotetext{
${ }^{9}$ Official Journal Nr L 135 z 31 V 1994 r.

${ }^{10}$ M. Zaleska: Zmiany zasad gwarantowania depozytów w odpowiedzi na globalny kryzys finansowy, w: J. Nowakowski (red) Instrumenty i regulacje bankowe w czasie kryzysu, Difin, Warszawa 2010, s. 20-22.
} 
depozytów. Europejski System Gwarantowania Depozytów (ESGD) miałby bowiem być zbudowany na dotychczasowym systemie przez połączenie krajowych systemów gwarantowania depozytów oraz być zarządzany przez Jednolitą Radą ds. Restrukturyzacji i Uporządkowanej Likwidacji. Byłby to system obowiązkowy dla państw strefy euro, których banki obejmuje obecnie Jednolity Mechanizm Nadzorczy; a dobrowolny dla innych krajów UE, pragnących przystąpić do unii bankowej. System ten byłby jednak tworzony etapami, przy czym:

- w pierwszym etapie (lata 2017-2019) krajowe systemy gwarantowania depozytów miałyby dostęp do ESGD dopiero po wyczerpaniu środków własnych, a środki zgromadzone w ESGD stanowiłyby źródło dodatkowych funduszy dla systemu krajowego, lecz tylko do pewnego poziomu,

- w drugim etapie (lata 2020-2023) system zostałby przekształcony w system stopniowo uwspólniany, a systemy krajowe nie byłby zobowiązane do wyczerpania środków własnych przed uzyskaniem dostępu do środków ESGD - środki te byłyby dostępne natychmiast, gdy tylko pojawiłaby się konieczność częściowego pokrycia z nich wypłat na rzecz deponentów,

- w trzecim etapie (od 2024) nastąpiłaby pełna integracja systemów.

$\mathrm{Na}$ wszystkich trzech etapach ESGD zarówno zapewniałby finansowanie, jak i pokryłby straty uczestniczących systemów gwarantowania depozytów. Finansowanie zapewniane przez ESGD będzie przy tym obejmować zaspokojenie początkowego zapotrzebowania na płynność uczestniczącego systemu gwarantowania depozytów w celu wypłaty środków deponentom w wymaganym terminie ( $7 \mathrm{dni}$ roboczych), jak też w celu terminowego dokonania wkładu na rzecz restrukturyzacji i uporządkowanej likwidacji. Uczestniczący system gwarantowania depozytów będą jednak musieli zwrócić środki finansowe Jednolitej Radzie ${ }^{11}$.

Warto jednak zauważyć, iż budowa Europejskiego Systemu Gwarantowania Depozytów w przedstawionym powyżej kształcie nie zakłada jakichkolwiek istotnych zmian $\mathrm{w}$ poziomie ochrony deponentów. Obecne rozwiązania $\mathrm{w}$ tym zakresie są wynikiem przyjęcia w dniu 16 kwietnia 2014 r. przez Parlament Europejski i Radę Dyrektywy 2014/49/UE w sprawie systemów gwarancji depozytów, której to postanowienia zostały implementowane we wszystkich krajach UE. W Polsce w pełni weszły one w życie w dniu 9 października 2016 roku na podstawie ustawy z dnia 10 czerwca 2016 r. o Bankowym Funduszu Gwarancyjnym, systemie gwarantowania depozytów oraz przymusowej restrukturyzacji. Zgodnie z nimi ochronie gwarancyjnej podlegają środki pieniężne zgromadzone przez deponenta na rachunkach bankowych, $\mathrm{w}$ przypadku których deponent jest stroną umowy do wysokości równowartości w złotych 100000 euro - w całości.

Ochrona gwarancyjna nie obejmuje jednak:

- środków wpłaconych tytułem udziałów, wpisowego i wkładów członkowskich do spółdzielni,

- środków deponenta, jeżeli środki te znajdują się na rachunkach bankowych, na których w okresie 2 lat przed dniem spełnienia warunku gwarancji nie dokonano obrotów poza dopisywaniem odsetek lub pobieraniem prowizji lub

${ }^{11}$ Proposal for a Regulation of the European Parliament and of the Council amending Regulation (EU) 806/2014 in order to establish a European Deposit Insurance Scheme, COM(2015) 586 final, s. 11 - 15. 
opłat, a ich suma jest niższa niż równowartość w złotych 2,5 euro - jeżeli byłyby to jedyne środki deponenta objęte ochroną gwarancyjną,

- pieniądza elektronicznego oraz środków pieniężnych otrzymanych w zamian za pieniądz elektroniczny.

Wyjątkiem od ogólnej zasady na korzyść deponenta będącego osobą fizyczną jest traktowanie środków lub należności pochodzących z:

- odpłatnego zbycia (jeżeli zbycie to nie nastąpiło w ramach wykonywanej działalności gospodarczej):

$=$ nieruchomości zabudowanej budynkiem mieszkalnym jednorodzinnym, jej części lub udziału w takiej nieruchomości,

= prawa użytkowania wieczystego gruntu zabudowanego budynkiem mieszkalnym jednorodzinnym lub udziału w takim prawie,

= samodzielnego lokalu mieszkalnego stanowiącego odrębną nieruchomość lub udziału w takim lokalu, gruntu lub udziału w gruncie albo prawa użytkowania wieczystego gruntu lub udziału w takim prawie, związanych $\mathrm{z}$ tym lokalem,

= spółdzielczego własnościowego prawa do lokalu o przeznaczeniu mieszkalnym lub udziału w takim prawie,

- wykonania na jego rzecz umownego lub sądowego podziału majątku po ustaniu małżeńskiej wspólności majątkowej,

- nabycia przez niego spadku, wykonania na jego rzecz zapisu lub otrzymania zachowku,

- wypłaty sumy ubezpieczenia z tytułu umowy ubezpieczenia na życie w związku ze śmiercią osoby ubezpieczonej lub dożyciem przez nią oznaczonego wieku,

- wypłaty sumy ubezpieczenia $\mathrm{z}$ tytułu umowy ubezpieczenia następstw nieszczęśliwych wypadków w związku z uszkodzeniem ciała, rozstrojem zdrowia lub śmiercią osoby ubezpieczonej wskutek nieszczęśliwego wypadku,

- wypłaty odprawy pieniężnej na warunkach i w wysokości określonych w przepisach odrębnych,

- wypłaty odprawy emerytalnej lub rentowej,

które są one objęte ochroną gwarancyjną, w terminie 3 miesięcy od dnia wpływu środków na rachunek lub powstania należności, do wysokości stanowiącej różnicę pomiędzy dwukrotnością limitu 100000 euro a sumą pozostałych środków i należności deponenta, objętych ochroną gwarancyjną, nie wyższą jednak niż limit 100000 euro. Po tym terminie środki i należności są objęte obowiązkowym systemem gwarantowania depozytów na „zwykłych” zasadach. Dodatkowo w przypadku gdy środki lub należności deponenta będącego osobą fizyczną pochodzą z wypłaty odszkodowania za szkodę wyrządzoną przestępstwem lub zadośćuczynienia za doznaną krzywdę, odszkodowania lub zadośćuczynienia są one objęte ochroną gwarancyjną, w terminie 3 miesięcy od dnia wpływu środków na rachunek lub powstania należności - w całości. Po tym terminie te środki i należności są objęte obowiązkowym systemem gwarantowania depozytów na „zwykłych” zasadach.

Środki gwarantowane są płatne w złotych, w terminie 7 dni roboczych od dnia spełnienia warunku gwarancji. Terminu nie stosuje się, w odniesieniu do całości lub 
części świadczenia, w przypadku gdy dotyczą IKE, IKZE lub środków gwarantowanych ponad standardowy limit 100000 euro $^{12}$.

Reasumując powyższą ewolucję należy zwrócić uwagę na dwie zasadnicze kwestie, tj. wzmocnienie ochrony zarówno poprzez podniesienie limitu środków gwarantowanych (z 20 tys. do 100 tys. euro) wraz z likwidacja ,udziału własnego" deponenta oraz radykalne skrócenie czasu niedostępności środków dla deponenta (z 3 miesięcy do 7 dni roboczych).

\section{Podsumowanie}

Zestawiając społeczne koszty utworzenia i funkcjonowania systemu gwarantowania depozytów z kosztami skutków paniki na rynku bankowym należy jednak uwzględnić wszystkie kategorie kosztów zarówno bezpośrednich, jak i pośrednich. Kosztami bezpośrednimi są przede wszystkim składki płacone przez banki, które zmniejszają oprocentowanie depozytów i zwiększają koszt kredytu bankowego dla społeczeństwa. Pośrednim, społecznym kosztem funkcjonowania systemów gwarantowania depozytów jest zaś osłabienie mechanizmów oddziaływania rynkowego poprzez redukcję motywacji deponentów do interesowania się sytuacją banku oraz wzrost ryzyka powstania pokusy nadużycia $^{13}$.

Kształt systemu gwarantowania depozytów jest pochodną zaburzeń i zdarzeń kryzysowych w sektorze bankowym. Podczas trwania kryzysu, jak też niedługo po jego przezwyciężeniu dużo łatwiej jest przeprowadzić zmiany w sieci bezpieczeństwa, w tym w systemie gwarantowania depozytów niż w czasie stabilnej sytuacji na rynku, kiedy to skłonność do ustępstw i kompromisów jest co do zasady mniejsza ${ }^{14}$. Należy jednak zauważyć, iż często zmiany w systemie gwarantowania depozytów, które następują podczas kryzysu mogą być dla niego niekorzystne. Rozwiązania wprowadzane podczas kryzysu powinny mieć zatem jedynie doraźny charakter i ściśle ograniczony czas obowiazywania. Nawet jednak ta konstrukcja ma swoje wady, gdyż powoduje ona powstanie oczekiwania deponentów, iż w przypadku kolejnego kryzysu rząd zareaguje podobnie jak wcześniej i znów wprowadzi np. podwyższone lub nielimitowane gwarancje. Tym samym deponenci nawet przy limitowanych gwarancjach straca $\mathrm{w}$ takiej sytuacji motywację do oddziaływania na banki, a w bankach wzrośnie ryzyko pokusy nadużycia ${ }^{15}$. Regulacje długoterminowe powinny być zaś wprowadzane bez nacisków i presji, wynikającej z zaburzeń na rynkach. Trzeba być jednak świadomym, iż brak zainteresowania ze strony deponentów będzie powodował brak zainteresowania polityków pracami nad takimi regulacjami ${ }^{16}$.

\footnotetext{
${ }^{12}$ M. Zaleska: System gwarantowania depozytów, w: Zaleska M. (red) Świat bankowości, Difin, Warszawa 2018, s. 102

${ }^{13}$ A. Demirgüç-Kunt, E. J. Kane: Deposit Insurance Around the Globe: Where Does It Work? Journal of Economic Perspectives 2002, Volume 16, Number 2-Spring, s. 175-195.

${ }^{14}$ A. Demirgüç-Kunt, E. J. Kane, L. Laeven: Adoption and Design of Deposit Insurance, w: A. DemirgüçKunt, E. J. Kane, L. Laeven (red) Deposit insurance around the world. Issues of design and implementation, MIT Press, Cambridge 2008, s. 70.

${ }^{15}$ T. L. Hogan, K. Johnson: Alternatives to the Federal Deposit Insurance Corporation, Independent Review 2016, Volume 20, Issue 3, s. 435.

${ }^{16}$ J. Koleśnik: Bezpieczeństwo systemu bankowego. Teoria i praktyka, Difin, Warszawa 2011, s. 219.
} 
Podsumowując społeczne aspekty gwarantowania depozytów w bankach należy zwrócić także uwagę, iż jego funkcjonowanie nie stwarza jakichkolwiek bodźców do zwiększania wiedzy deponentów w zakresie ekonomii i finansów a ich świadome decyzje ograniczają się jedynie do dywersyfikacji depozytów pomiędzy bankami, do wysokości środków gwarantowanych. Dywersyfikacja ta będąca następstwem istnienia limitu środków gwarantowanych prowadzi jednak do zwiększenia kosztów usług depozytowych ponoszonych przez deponentów ${ }^{17}$. Na podstawie obserwacji ostatniego światowego można zaś uznać, iż podnoszenie limitu środków gwarantowanych lub wprowadzanie nieograniczonych gwarancji ma pozytywny wpływ na zachowanie deponentów tylko w krótkim okresie czasu, przyczyniając się do ograniczenia, czy nawet niedopuszczenia do paniki na rynku. Jednak w dłuższym horyzoncie czasu skutki takiego działania mogą być wręcz odwrotne.

\section{Bibliografia}

Bagus P., Howden D.: The economic and legal significance of "full" deposit availability, European Journal of Law and Economics 2016, vol. 41, issue 1, s. 243-254.

Bartholdy J., Boyle G. W., Stover R. D.: Deposit insurance and the risk premium in bank deposit rates, Journal of Banking and Finance 2003, vol. 27, issue 4, s. 699-717.

Bergbrant M. C., Campbell K. C., Hunter D. M., Owers J. E.: Does deposit insurance retard the development of non-bank financial markets? Journal of Banking and Finance 2016, vol. 66, s. 102125.

Cooper R., Kempf H.: Deposit insurance and bank liquidation without commitment: Can we sleep well? Economic Theory 2016, vol. 61, issue 2, s. 365-392.

Demirgüç-Kunt A., Kane E. J.: Deposit Insurance Around the Globe: Where Does It Work? Journal of Economic Perspectives 2002, vol. 16, no. 2, s. 175-195.

Demirgüç-Kunt A., Kane E. J., Laeven L.: Adoption and Design of Deposit Insurance, w: Demirgüç-Kunt A., Kane E. J., Laeven L. (red) Deposit insurance around the world. Issues of design and implementation, MIT Press, Cambridge 2008.

Demirgüç-Kunt A., Kane E. J., Laeven L.: Determinants of deposit-insurance adoption and design, Journal of Financial Intermediation 2008, vol. 17, issue 3, s. 407-438.

Dyrektywa Parlamentu Europejskiego i Rady 2014/49/UE z dnia 16 kwietnia 2014 r. w sprawie systemów gwarancji depozytów (Official Journal Nr L 173 z 12 VI 2014 r.).

Dyrektywa Parlamentu Europejskiego i Rady 94/19/WE z dnia 30 maja 1994 r. w sprawie systemu gwarantowania depozytów (Official Journal Nr L 135 z 31 V 1994 r.).

Hogan T. L., Johnson K.: Alternatives to the Federal Deposit Insurance Corporation, Independent Review 2016, vol. 20, no. 3, s. 433-454.

Huizinga H., Nicodème G.: Deposit insurance and international bank liabilities, Journal of Banking and Finance 2006, Volume 30, Issue 3, s. 965-987.

Kaufman G. G., Eisenbeis R. A.: Deposit Insurance Issues in the Post-2008 Crisis World, w: Berger A. N., Molyneux P., Wilson J. O.S. (red) The Oxford handbook of banking, Oxford University Press 2015.

Koleśnik J.: Bezpieczeństwo systemu bankowego. Teoria i praktyka, Difin, Warszawa 2011.

Proposal for a Regulation of the European Parliament and of the Council amending Regulation (EU) 806/2014 in order to establish a European Deposit Insurance Scheme, European Commission, $\operatorname{COM}(2015) 586$ final.

${ }^{17}$ G. G. Kaufman, R. A. Eisenbeis: Deposit Insurance Issues in the Post-2008 Crisis World, w: A. N. Berger, P. Molyneux, J. O.S. Wilson (red) The Oxford handbook of banking, Oxford University Press, 2015, s. 546-547. 
Raport Roczny BFG za 2015 rok, Bankowy Fundusz Gwarancyjny, Warszawa 2016.

Sektor bankowy dane 2016, Urząd Komisji Nadzoru Bankowego, Warszawa 2017.

Ustawa z dnia 10 czerwca 2016 r. o Bankowym Funduszu Gwarancyjnym, systemie gwarantowania depozytów oraz przymusowej restrukturyzacji (Dz.U.2016.996).

Zaleska M.: System gwarantowania depozytów, w: Zaleska M. (red) Świat bankowości, Difin, Warszawa 2018.

Zaleska M.: Zmiany zasad gwarantowania depozytów w odpowiedzi na globalny kryzys finansowy, w: J. Nowakowski (red) Instrumenty i regulacje bankowe w czasie kryzysu, Difin, Warszawa 2010.

\section{Summary}

The purpose of this article is to present the social premises for the creation and consequence of the existence of deposit guarantee schemes. According to the author, the existence of deposit guarantee schemes makes them an important factor strengthening the relationship between depositors and banks, but their shape is a derivative of crisis in the banking sector. Comparing the social costs of creating and operating a deposit guarantee scheme with the cost of panic on the banking sector, the direct costs are primarily the contributions paid by banks, which reduce interest rates on deposits and increase the cost of bank credit to the public. The indirect cost is an increase of moral hazard risk and weakened incentives for deepening depositors' knowledge of economics and finance.

Key words: banking system, deposit guarantee scheme, moral hazard

Informacje o autorze:

dr hab. Jan Koleśnik, prof. SGH

Szkoła Główna Handlowa w Warszawie

Kolegium Ekonomiczno-Społeczne

Instytut Bankowości

al. Niepodległości 162, 02-554 Warszawa

e-mail: jan.kolesnik@sgh.waw.pl

ORCID: 0000-0003-2182-5645 